\title{
Beneficial Effects of Nadisudhi Pranayama on Cardio-Respiratory Parameters
}

\author{
Sivagami $\mathbf{G}^{1}$, Milind V Bhutkar ${ }^{2}$ \\ ${ }^{1}$ Assistant Professor, ${ }^{2}$ Professor \& HOD, Dept. of Physiology, VMKV Medical College, Salem.
}

\begin{abstract}
Introduction: Pranayama is the breath control practice to control body energies. Nadisudhi means, 'the purification of the invisible energy channels.' Practice of Nadisudhi pranayama causes feeling of freshness, energy and lightness of body and mind. Regular pranayama practice causes many desirable physical, physiological and psychological changes in an individual.

Aim \& Objectives: The study was designed to assess the beneficial effects of Nadisudhi pranayama on cardiorespiratory parameters.

Materials \& Methods: 60 young healthy subjects in the age group of 17-24 years were selected for the study. They received Nadisudhi pranayama training of 6 days a week for 6 weeks. Pulse rate, Blood pressure \& Peak expiratory flow rate (PEFR) were recorded before and after 6 weeks of training.

Results: Results were analyzed by using paired't' test. There was significant decrease in Pulse rate, Blood pressure and increase in Peak expiratory flow rate after practice of Nadisudhi pranayama. Decrease in Pulse rate, Blood pressure after practice of Nadisudhi pranayama could be due to increase in parasympathetic activity \& decrease in sympathetic activity. Improvement in Peak expiratory flow rate could be due to increase in surface area of the alveolar membrane, acclimatization of respiratory centers to high PCO2 \& strengthening of the respiratory muscle in Nadisudhi pranayama trained persons.

Conclusion: Nadisudhi pranayama is effective in lowering the Pulse rate, Blood pressure \& improve the Peak expiratory flow rate. It may be an effective non pharmacological intervention in clinical conditions like bronchial asthma, early bronchitis and hypertension.
\end{abstract}

Key words: Nadisudhi pranayama, Pulse rate, Blood pressure, Peak expiratory flow rate.

\section{INTRODUCTION:}

Y oga is a science practiced in India over thousands of years. It is one of the best lifestyle modification ever devised in the history of mankind. Special and specific breathing techniques called pranayama have been evolved in yoga to transcend the limits of our physical and mental abilities experienced in our everyday life. ${ }^{1}$ 'Prana' means breath, respiration, vitality or energy.
'Ayama' means expansion or stretching. Pranayama is an art of controlling the breath. Pranayama produces many systemic and psychophysical effects besides its specific effects on respiratory functions. Nadishudhi pranayama helps to maintain balance between the nadis. According to ancient Yoga literature, 'Nadi' refers to a channel through which energy flows within a body.

Pranayama when performed regularly has benefits 
on various systems (respiratory system, cardiovascular system, central nervous system) of the body.

Peak expiratory flow rate is a measure of the maximum expiratory flow rate sustained by a subject for at least 10 milliseconds starting from the level of maximum lung inflation expressed in liters per minute (lit/min). ${ }^{2}$ It is one of the valuable tools for evaluating the functions of respiratory system. It is the simple screening procedure performed using Wrights peak flow meter. ${ }^{3}$

Pulse rate and Blood pressure are the parameters evaluated for the functioning of cardiovascular system.

\section{AIMAND OBJECTIVES:}

The aim of study is to know the effects of 'Nadisudhi' Pranayama practice on cardiac parameters (Blood Pressure \& Pulse rate) and Respiratory parameters (PEFR).

Objectives of the study are 1) to determine the Blood pressure, Pulse rate and Peak expiratory flow rate before pranayama and after pranayama, 2) to compare the cardio respiratory parameters before and after 6 weeks of Nadisudhi pranayama practice and 3 ) to provide the scientific explanation for the difference.

\section{MATERIALSAND METHODS:}

The study group consists of 60 young healthy people from Vinayaka Mission Kirupananda Variyar Medical College, Salem, in the age group 17-24 years. Written informed consent was taken from all the subjects. They were trained in Nadisudhi pranayama for 6 weeks. They were trained for 30 minutes a day in the evening time between 4.30 to $5 \mathrm{pm}$ for six days per week. All of them followed balanced vegetarian diet. The first phase of recording of cardiac \& respiratory parameters was done at the beginning of the study. The second phase of recording was done after 6 weeks of regular pranayama practice.

\section{Inclusion criteria:}

Young healthy medical students aged between 1724 years who were untrained in yoga previously.

\section{Exclusion criteria:}

The subjects with history of Allergic disorders or respiratory disorders, smoking, alcohol intake, Systemic disease like Diabetes and Hypertension, other cardiovascular disorders, Collagen disorders, Acute illness, Treatment with beta-agonists or xanthene group of drugs. Chest deformities and respiratory disorders were ruled out by history and clinical examination.

\section{Parameters studied:}

Peak expiratory flow rate (PEFR): PEFR was measured by using Wright's peak flow meter. ${ }^{3}$ Mouthpiece of Peak flow meter was placed over the lips and made sure there were no gaps for air to escape. The subjects were instructed to inspire maximally by putting their maximum effort, followed by breathing out maximally into the peak flow meter with the nose clipped. PEFR was recorded thrice and the highest of three readings was taken in lit/min.

Pulse Rate: Pulse rate was counted in sitting position after 5 min of rest and it was counted by palpation in the radial artery for one whole minute.

Recording of Blood pressure: Blood pressure was measured with a standard manual Mercury sphygmomanometer with adult size cuff and 
stethoscope. It was recorded in sitting posture after 5 min of rest. Both systolic blood pressure (SBP) and Diastolic blood pressure (DBP) were measured at rest before the practice of Nadisudhi pranayama and after 6 weeks of pranayama training.

\section{RESULTS AND ANALYSIS}

Descriptive statistical analysis has been carried out in the present study. Results are presented as Mean \pm SD. Significance is assessed at $5 \%$ level of significance. Student paired't' test was used to compare the differences between before \& after 6 weeks of Nadisudhi pranayama.

Table1: Comparison of effect of 6 weeks Nadisudhi pranayama on Cardiac parameters

\begin{tabular}{|c|c|c|c|}
\hline Variables & $\begin{array}{c}\text { Before } \\
\text { pranayama }\end{array}$ & $\begin{array}{c}\text { After } \\
\text { pranayama }\end{array}$ & p value \\
\hline $\begin{array}{c}\text { Systolic Blood pressure } \\
(\mathrm{mmHg})\end{array}$ & $117 \pm 2.161$ & $108.3 \pm 1.907$ & $<0.0001$ \\
\hline $\begin{array}{c}\text { Diastolic Blood pressure } \\
(\mathrm{mmHg})\end{array}$ & $76.40 \pm 4.130$ & $70.93 \pm 3.404$ & $<0.0001$ \\
\hline Pulse rate (per min) & $77.03 \pm 3.002$ & $72.40 \pm 3.247$ & $<0.0001$ \\
\hline
\end{tabular}

As shown in Table 1, Systolic blood pressure, Diastolic blood pressure and Pulse rate were decreased and statistically significant $(\mathrm{P}<0.0001)$.

Table 2. Comparison of effect of 6 weeks Nadisudhi pranayama on Respiratory parameters

\begin{tabular}{|c|c|c|c|}
\hline Variables & $\begin{array}{c}\text { Before } \\
\text { pranayama }\end{array}$ & $\begin{array}{c}\text { After } \\
\text { pranayama }\end{array}$ & p value \\
\hline PEFR ( L / min) & $359.66 \pm 7.583$ & $429 \pm 7.431$ & $<0.0001$ \\
\hline
\end{tabular}

As shown in Table 2 PEFR - before pranayama was $359.66 \pm 7.583 \mathrm{~L} / \mathrm{min} \&$ after pranayama was $429.16 \pm 7.431 \mathrm{~L} / \mathrm{min}$ which is statistically significant $(\mathrm{P}<0.001)$

\section{DISCUSSION :}

Yoga calms and relaxes the mind, strengthens and tunes the body, and brings them into harmony with one another. Yogic breathing techniques are very important for inducing relaxation. Nadisudhi pranayama is the type of pranayama, when performed regularly has benefits on various systems (respiratory system, cardiovascular system, central nervous system) of the body.

Cardiac parameters which include Blood Pressure \& Heart rate were found to be significantly decreased as shown in Table 1 and PEFR, the respiratory parameter was increased as shown in Table 2. These results were consistent with other studies like Jerath et al. ${ }^{4}$ and Makwana et $\mathrm{al}^{5}$

Jerath et al have reported that, in pranayama the individual prolongs the phase of inhalation voluntarily, so that, lungs are expanded considerably and the walls of the alveoli are stretched to the maximum. Stretching of lung tissue acts through slowly adapting stretch receptors (SASR) and produce inhibitory signals to decrease the tracheo - bronchial smooth muscle tone which leads to decrease in air flow resistance. This improves dynamic parameters of lung function test. Pranayamic breathing also causes stretching of connective tissue fibroblasts surrounding the lung tissue which are capable of affecting the membrane potential of nervous tissue by generating the hyperpolarization current. Both inhibitory impulses from SASR and hyperpolarization current enhance the synchronisation between lungs and cortex. ${ }^{4}$

The stretch receptors are thus trained to withstand more stretching because of regular practice of pranayama. This helps them to hold the breath for a 
longer period, so that the respiratory center is gradually acclimatized to withstand a high PCO2 concentration in the arterial blood. ${ }^{4}$

A Study done by Hilderbran et al in exercised rat has reported that maximum inflation and deflation is an important physiological stimulus for the release of surfactant. One of the functions of surfactant is to increase the lung compliance. ${ }^{5}$

Yogic breathing raises the diaphragm to a higher level than its normal excursion which means more vertical breathing than horizontal breathing. ${ }^{6}$ The sitting posture is fixed while performing pranayama breathing through alternate nostrils which promotes the vertical breathing. By this vertical breathing all the alveoli of both the lungs open out evenly. Due to the even expansions of all the alveoli a vast expanse of alveolar membrane is available for exchange of gases \& larger surface area is available for the process of diffusion.

During pranayama training, regular inspiration and expiration for prolonged periods inflate and deflate the lungs maximally. Yogic breathing causes strengthening of respiratory muscles and enhances the endurance of respiratory muscles. ${ }^{7,8}$

So pranayama practice can probably strengthen the respiratory muscles, increase the surface area of the alveolar membrane, and acclimatize the respiratory centers to high $\mathrm{PCO} 2$ as evidenced by increase in PEFR.

Decrease in pulse rate and blood pressure results were consistent with other studies like Bhargava et al.(1988) ${ }^{9}$, Varun Malhotra et al (2009) ${ }^{10}$, Upadhyay Dhungel et al (2008) $)^{11}$

All these studies explain that, following pranayama practice both the components of the autonomic nervous system viz parasympathetic and sympathetics are activated. A decrease in pulse rate $\&$ Blood pressure may be related to an increase in parasympathetic activity (vagal tone) and a decrease in cardiac sympathetic activity. ${ }^{9,10,11}$

In a study conducted by Subbalakshmi et al, Nadishodana pranayama practice was done for 20 minutes duration and they have showed a decrease in heart rate \& systolic blood pressure where as in our study with 6 weeks of pranayama practice, pulse rate \& blood pressure values were significantly decreased. ${ }^{12}$

In pranayama, subjects not only try to breathe, but at the same time also try to keep his / her attention on the act of breathing, leading to improved concentration. These acts of concentration remove his attention from worldly worries and de-stress him / her. This stress free state of mind evokes relaxed responses. In this relaxed state, parasympathetic nerve activity overrides sympathetic nerve activity. ${ }^{13}$ Therefore the significant decline in basal heart rate and systolic blood pressure in the pranayama practice could be largely due to better parasympathetic control over the heart.

Raghuraj et al (1998) also have reported that slow pranayama (nadishudhi) increases parasympathetic activity. ${ }^{14}$

Madanmohan et $\mathrm{al}^{15}$ have reported that pranayama training, produces a significant decrease in the load on the myocardium coupled with an overall reduction in oxygen consumption and metabolic rate as found in earlier studies done by Telles et al $(1994)^{16}$ Raghuraj et al (1998) $)^{14}$ and Raju et al (1994). ${ }^{17}$ Pranayama training modulates ventricular performance by altering the cardiac autonomic 
tone. The changes in ventricular performance are brought about by increased parasympathetic and decreased sympathetic activity.

So pranayama practice can probably increase the parasympathetic activity \& decrease the sympathetic activity as evidenced by decrease in Pulse rate and Blood pressure.

\section{CONCLUSION :}

Regular practice of Nadisudhi pranayama improves the Peak expiratory flow rate and reduces the Blood pressure and Pulse rate.

Decrease in Pulse rate and Blood pressure indicates that Nadisudhi pranayama practice can be advised to hypertensive patients as a simple exercise along with the medical therapy. The increase in PEFR by Nadisudhi pranayama practice obviously offers an increment in cardiorespiratory efficiency and it can be advocated to the patients with early bronchitis and as a preventive measure for COPD.

\section{REFERENCES:}

1. Sivapriya DV, Suba Malani S, Shyamala Thirumeni. Effect of Nadi shodhana pranayama on respiratory parameters in school students. Recent Research in Science and Technology. 2010;2(11):32-39.

2. Tran MD, Holly RG, Lashbrook J, Amsterdam EA. Effects of hatha yoga practice on health related aspects of physical fitness. Prev Cardiol. 2001; 4(4): 165-170.

3. Nunn AJ, Gregg I. New regression equations for predicting peak expiratory flow in adults. Br. Med. J. 1989; 298: 1068-1070.

4. Jerath R, Edry J, Barnes V, Jerath V. Physiology of long pranayamic breathing:
Neural respiratory elements may provide a mechanism that explains how slow deep breathing shift the autonomic nervous system. Med Hypotheses. 2006; 67(3):566571.

5. Hilderbran JN, Georke J, Clements JA. Surfactant release exercised rat lung stimulated by air inflation. J Applied physiol. 1981; 51:905-910.

6. Makwana K, Khirwadkar B, Gupta HC. Effect of short-term yoga practice on ventilatory function tests. Indian J Physiol Pharmacol. 1988; 32: 202-208.

7. Madanmohan, Udupa K, Bhavanani AB, Shatapathy CC, Sahai A. Modulation of cardiovascular response to exercise by yoga training. Indian J Physiol Pharmacol. 2004; 48(4): 461-465.

8. Shankarappa V, Prashanth P, Nachal Annamalai, Varunmalhotra. The short Term Effect of Pranayama on the Lung Parameters. Journal of Clinical and Diagnostic Research. 2012; 6(1):27-30.

9. Bhargava R, Gogate MG and Mascarenhas JF. Autonomic responses to breath holding and its variation following pranayama. Indian J. Physiol, Pharmacol. 1988; 32: 257264.

10. Varun Malhotra, OP Tandon, Rajkumar Patil, Tarun K Sen, Stany W Lobo, Nagamma T, et.al. Suryanadi Anuloma Viloma Pranayama Modifies Autonomic Activity of Heart. The Journal of Yoga. 2009; 8(1).

11. Upadhyay KD, Malhotra V, Sarkar D, Prajapati R. Effects of alternate nostril 
breathing exercises on cardio respiratory functions. Nepal medical coll J. 2008; 10(1): 25-27.

12. Subbalakshmi NK, Saxena SK, Urmimala, and Urban JA. D'Souza. Immediate effect of 'nadi -shodhana pranayama' on some selected parameters of cardiovascular, pulmonary, and higher functions of brain. Thai journal of physiological sciences. August 2005; 18 (2):10-16.

13. Udupa KN, Singh RH, and Settiwar RM. Studies on the effect of some yogic breathing exercises (pranayama) in normal persons. Indian J Med Res. 1975; 63: 1062-1065.

14. Raghuraj P, Ramakrishnan AG, Nagendra HR, Telles S. Effect of two selected yogic breathing techniques on heart rate variability. Indian J Physiol Pharmacol. 1998; 42: 467472.
15. Kaviraja Udupa, Madanmohan, Ananda Balayogi Bhavanani, Vijyalakshmi P, Krishnamurthy N. Effect of pranayama training on cardiac function in normal young volunteers. Indian J Physiol Pharmacol. 2003; 47 (1): 27-33.

16. Telles S, Nagarathna R, Nagendra HR. Breathing through a particular nostril can alter metabolism and autonomic activities. Indian J Physiol Pharmacol. 1994; 38(2): 133-137.

17. Raju PS, Madhavi S, Prasad KVV, Reddy MV, Reddy ME, Sahay BK et.al. Comparison of effects of yoga and physical exercise in athletes. Indian J Med Res. 1994; 100: 81-87.

Received on 15/10/2017 Revised on 20/11/2017 Accepted on 24/11/2017 